\title{
Perbedaan Skor Nyeri pada Anak dengan Pemberian Madu Setelah Dilakukan Tindakan Pemasangan Infus
}

\author{
Sintiya Halisya Pebriani ${ }^{1}$, Irwadi $^{2}$ \\ ${ }^{1}$ Program Studi DIII Keperawatan, STIK Siti Khadijah Palembang, Indonesia \\ ${ }^{2}$ Program Studi Ners, STIK Siti Khadijah Palembang, Indonesia \\ Email: sintiyahp88@gmail.com
}

\begin{abstract}
The Difference Scores of Pain in Children with Giving of Honey after Intravenous Fluid Therapy. Intravenous fluid therapy in a child in the emergency room may lead to prolonged trauma and is a procedure that can cause anxiety, fear and uncomfortable pain. Handling of pain in children can be done with non-pharmacological techniques that are by giving a sweet taste of honey, wherein honey contains flavonoid content that can inhibit the pain. The purpose of this study was to know differences in pain scores after the installation of infusion between groups of children given honey and not given honey. The research design used in the form of quasi-experiment with nonequivalent control group type, post-only design, with the number of samples were 34 people who met the inclusion criteria. The sample was divided into two groups: the intervention group who received honey peroral (17 respondents) and the control group who did not get honey peroral (17 respondents), with age of respondent 1-6 years. Pain scores were evaluated with Children's Hospital of the Eastern Ontario Pain Scale (CHEOPS). A statistical test was using Mann-Whitney test with 95\% $(\alpha=0,05)$ incidence rate. The result showed that there was a difference in child pain score in intervention group and control group with $\mathrm{p}$ value $=0.000$. It can be concluded that there was an effect of giving honey to pain score, wherein the intervention group the pain score was lower than the control group, meaning that honey can reduce the pain response in children.
\end{abstract}

Keywords: Honey, Toddlers, Pain, Intravenous fluid therapy

\begin{abstract}
Abstrak: Perbedaan Skor Nyeri Pada Anak dengan Pemberian Madu Setelah Dilakukan Tindakan Pemasangan Infus. Terapi pemasangan infus pada anak di IGD dapat menimbulkan trauma berkepanjangan dan merupakan prosedur yang dapat menimbulkan kecemasan, ketakutan serta rasa nyeri yang tidak nyaman. Penanganan nyeri pada anak dapat dilakukan dengan tehnik nonfarmakologi yaitu dengan pemberian rasa manis berupa madu, dimana di dalam madu terdapat kandungan flavonoid yang dapat menghambat rasa nyeri tersebut. Tujuan penelitian ini adalah untuk mengetahui perbedaan skor nyeri setelah pemasangan infus antara kelompok anak yang diberikan madu dan tidak diberikan madu. Desain penelitian yang digunakan berupa quasi eksperiment dengan jenis nonequivalent control group, after only design dengan jumlah sampel sebanyak 34 orang yang memenuhi kriteria inklusi. Sampel terbagi menjadi dua kelompok yaitu kelompok intervensi yang mendapatkan madu peroral (17 responden) dan kelompok kontrol yang tidak mendapatkan madu peroral (17 responden), dengan usia responden 1-6 tahun. Skor nyeri dievaluasi dengan Children's Hospital of Eastern Ontario Pain Scale (CHEOPS). Uji statistik mengunakan Mann-Whitney test dengan tingkat kemanknaan 95\% $(\alpha=0,05)$ Hasil penelitian didapatkan bahwa terdapat perbedaan skor nyeri anak pada kelompok intervensi dan kelompok kontrol dengan $p$-value $=0.000$. Dapat disimpulkan bahwa ada pengaruh pemberian madu terhadap skor nyeri, dimana pada kelompok intervensi skor nyeri lebih rendah dibandingkan dengan kelompok kontrol, artinya madu dapat mengurangi respon nyeri pada anak.
\end{abstract}

Kata kunci: Madu, Anak, Nyeri, Pemasangan infus

Sehat dan sakit merupakan sebuah rentang yang dapat di alami oleh semua manusia, tidak terkecuali oleh anak. Anak dengan segala karakteristiknya memiliki peluang yang lebih besar untuk mengalami sakit jika dikaitkan dengan respon imun dan kekuatan pertahanan dirinya yang belum optimal (Mediani, 2005).

Anak yang sakit dan dibawa atau di rujuk ke rumah sakit akan memperoleh pengangan awal di Instalasi Gawat Darurat (IGD). Menurut Flynn (2011) IGD adalah salah satu bagian di 
rumah sakit yang menyediakan penanganan awal bagi pasien yang menderita sakit dan cedera, baik itu neonatal, anak-anak, remaja, dewasa dan orang tua. Sebagai salah satu ujung tombak pelayanan kesehatan di rumah sakit pelayanan gawat darurat memberikan pelayanan medis 24 jam baik itu dari dokter, bidan dan perawat.

Perawat sebagai salah satu dari tim medis di instalasi gawat darurat bertugas untuk melakukan intervensi yang cepat dan tepat dan meletakkan pasien sesuai dengan prioritas kebutuhan pasien agar dapat tindakan seoptimal mungkin, setelah diagnosa sementara di tegakan berdasarkan pemeriksaan klinis oleh dokter jaga IGD maka akan dilakukan terapi yaitu salah satunya tindakan pemasangan infus.

Menurut Mediani dkk (2005) selama prosedur tindakan pemasangan infus aktivitas perilaku anak akan menunjukkan bahwa anak mengalami nyeri terutama untuk kelompok anak usia 1-5 tahun (anak usia Toddler dan anak pra sekolah).

Rasa nyeri yang tidak tertangani dengan baik akan memberikan pengaruh buruk bagi fisik, emosi, perilaku, kognitif, dan psikologis. Pengaruh buruk yang dapat terjadi seperti ketakutan, kecemasan, penolakan untuk prosedur selanjutnya, penurunan ambang batas nyeri, pengurangan keefektifan analgesik, pobia terhadap jarum suntik, marah, perilaku agresif, ketidakmampuan berkonsentrasi dan ketidakpercayaan pada tenaga kesehatan. Selain itu juga dampak buruk terhadap fisik erat kaitannya dengan respon stress yang dapat mempengaruhi berbagai sistem tubuh, seperti fungsi kardiopulmoner (peningkatan tekanan darah, denyut jantung, dan frekuensi pernapasan), metabolisme, dan sistem imun. Adapun dampak jangka panjang nyeri yang dapat terjadi berupa insomnia, depresi, perubahan nafsu makan, dan kelelahan (Czarnecki, et al, 2011; Taddio, et al, 2010).

Penanganan nyeri dapat dilakukan dengan tehnik farmakologis maupun nonfarmakologis. Sejumlah tehnik farmakologi dapat dilakukan dengan analgetik, krim anastesi sedangkan nonfarmakologi seperti distraksi, relaksasi, guided imagery (Czarnecki, et al, 2011). Salah satu teknik distraksi yang dapat dilakukan adalah dengan pemberian rasa manis. Minuman manis yang mengandung glukosa atau fruktosa salah satunya adalah madu. Selain mengandung glukosa dan fruktosa madu juga memiliki kandungan flavonoid yang dapat menghambat nyeri yaitu dengan mekanisme kerja menghambat pembentukan prostaglandin melalui penghambatan enzim cyclooxygenase, sama seperti obat-obat analgetik (Goenarwo, 2011).

Berdasarkan hasil penelitian meta-analis yang dilakukan oleh Harrison et al (2014) menyebutkan pemberian rasa manis (sukrosa, glukosa dan permen karet manis) dapat menguangi nyeri pada anak usia 1-16 tahun. Larutan manis yang banyak mengandung sukrosa dan glukosa ini juga terdapat di dalam madu.

Tujuan penelitian ini adalah untuk mengetahui perbedaan skor nyeri pada kelompok anak yang diberi madu dan tidak diberi madu setelah pemasangan infus di IGD Rumah Sakit Islam Siti Khadijah Palembang. Penelitian ini di harapkan memberikan informasi bagi tenaga kesehatan maupun masyarakat tentang teknik penanganan nyeri dengan tanpa pemberian obat (nonfarmakologis) yaitu dengan mengkonsumsi madu yang manfaatnya dapat mengurangi rasa nyeri.

\section{METODE}

Desain penelitian yang digunakan berupa quasi eksperiment dengan jenis nonequivalent control group, after only design, yaitu penelitian yang menguji coba suatu intervensi pada kelompok subjek dengan kelompok pembanding dimana pemilihan subjek kelompok tidak di acak dan pengukuran penelitian tidak dilakukan sebelum intervensi, pengukuran hanya dilakukan setelah dilakukan intervensi (Dharma, 2011; Polit \& Beck, 2012).

Populasi dalam penelitian ini adalah anak dengan usia 1-6 tahun yang masuk ke Ruangan IGD Rumah Sakit Islam Siti Khadijah Palembang Tahun 2017. Jumlah sampel penelitian adalah 17 orang kelompok intervensi yaitu kelompok anak yang diberikan madu setelah tindakan pemasangan infus dan 17 orang kelompok kontrol yaitu kelompok anak yang tidak diberi madu setelah tindakan pemasangan infus, sehingga jumlah sampel adalah 34 orang. Teknik pengambilan sampel yang digunakan adalah dengan menggunakan nonprobability sampling jenis consecutive sampling. Pada consecutive sampling semua subyek yang datang secara berurutan dan memenuhi kriteria pemilihan dimasukkan dalam penelitian sampai jumlah subyek yang diperlukan terpenuhi (Sastroasmoro \& Ismael, 2011). Kriteria pemilihan subjek diantarnya anak dengan usia 1-6 tahun yang dilakukan pemasangan infus, belum pernah dilakukan pemasangan infus sebelumnya, orang tua/wali anak setuju untuk mengikuti penelitian dan menandatangani Informed Concent. 
Pemberian madu pada kelompok intrevensi ataupun kelompok kontrol dilakukan oleh peneliti dan di bantu oleh perawat ruangan. Pada pelaksanaan penelitian setelah dilakukan pemasangan infus kelompok intervensi segera diberikan madu dan tidak diberi madu untuk kelompok kontrol, kemudian dilakukan penilaian nyeri dengan menggunakan kuesioner Children's Hospital of Eastern Ontario Pain Scale (CHEOPS) dimana perawat mengobservasi tangisan, ekspresi wajah, verbal anak, batang tubuh, gerakan tangan anak (sentuhan) dan kaki.

CHEOPS dipilih sebagai standar baku (gold standard) dalam berbagai penelitian karena CHEOPS merupakan salah satu penilai nyeri observasi (metode observational Scale) pertama yang sangat baik digunakan dalam penilaian nyeri dan juga memiliki indikator pengukuran nyeri yang lebih lengkap terutama pada usia anak 3-7 tahun (Renovaldi dkk, 2014). Mengutip dari penelitian yang dilakukan oleh Sekriptini (2013) dimana hasil uji validitas dan reabilitas terhadap instrumen CHEOPS yaitu diperoleh nilai taraf signifikan $r$ product moment dengan jumlah responden 15 adalah 0,514 dengan tingkat kepercayaan $95 \%$ hasil tersebut menunjukkan bahwa instrument CHEOPS valid dan uji reabilitas dilakukan dengan uji inter-observer reliability dengan 2 numerator yang hasilnya diperoleh nilai cronbach's alfa 0,894 yang berarti terdapat kesepakatan yang kuat/sempurna diantara numerator secara signifikan.

Analisa data yang digunakan dengan menggunakan uji Mann-Whitney Test dengan tingkat kemaknaan 95\% $(\alpha<0,05)$. Proses ini menggunakan sistem komputerisasi program SPSS versi 19 for windows dengan taraf signifikansi $p<0,05$.

\section{HASIL}

\section{Karateristik Subyek Penelitian}

Tabel 1. Distribusi Subjek Berdasarkan Jenis Kelamin

\begin{tabular}{lrrrr}
\hline \multicolumn{3}{c}{$\begin{array}{c}\text { Jenis } \\
\text { Kelamin }\end{array}$} & \multicolumn{3}{c}{ Kelompok nak } \\
\cline { 2 - 5 } & Intervensi & \multicolumn{1}{c}{$\%$} & Kontrol & \multicolumn{1}{c}{} \\
\hline Laki-laki & 8 & 47,0 & 10 & 58,7 \\
\hline Perempuan & 9 & 52,8 & 7 & 41,2 \\
\hline Total & 17 & 100,0 & 17 & 100,0 \\
\hline
\end{tabular}

Tabel 2. Perbedaan Umur Subyek Penelitian Variabel Kelompok Anak p-

n

Dari tabel di atas dapat dilihat bahwa umur pada kedua kelompok tidak memiliki perbedaan yang bermakna $(p>0,05)$ artinya subjek pada penelitian ini dapat dibandingkan.

\section{Uji Normalitas}

Uji statistik untuk mengetahui normalitas data menggunakan Shapiro-Wilk Test. Hasil uji pada skor nyeri setelah pemasangan infus baik pada kelompok anak yang diberi madu dan tidak diberi madu adalah $p<0,05$ maka dikatakan data berdistribusi tidak normal sehingga uji statistik untuk mengetahui perdedaan skor nyeri kedua kelompok menggunakan uji nonparametric yaitu Mann-Whitney Test.

Tabel 3. Uji Normalitas Shapiro Wilk

\begin{tabular}{lcc}
\hline \multicolumn{1}{c}{ Variabel } & p-value \\
\hline $\begin{array}{l}\text { Skor nyeri kelompok anak diberi } \\
\text { madu }\end{array}$ & 0,000 \\
\hline $\begin{array}{l}\text { Skor nyeri kelompok anak tidak diberi } \\
\text { madu }\end{array}$ & 0,025 \\
\hline
\end{tabular}

\section{Uji Hipotesis}

Tabel 4. Skor Nyeri Pada Kelompok Intervensi dan Kontrol

\begin{tabular}{lcccc}
\hline \multirow{2}{*}{ Variabel } & \multicolumn{2}{c}{ Kelompok } & & \\
\cline { 2 - 4 } & $\begin{array}{c}\text { Intervensi } \\
\text { (madu) }\end{array}$ & $\begin{array}{c}\text { Kontrol } \\
\text { (tidak diberi } \\
\text { madu) }\end{array}$ & $\begin{array}{c}\boldsymbol{p} \text { - } \\
\text { value }\end{array}$ & $\mathbf{n}$ \\
\hline Skor nyeri & $5,00(4-13)$ & $8,00(6-13)$ & 0,000 & 34 \\
\hline
\end{tabular}

Dari tabel 4 diketahui bahwa skor nyeri pada kelompok intervensi yaitu 5,00 dengan skor terendah 4 dan skor tertinggi 13, sedangkan skor nyeri pada kelompok kontrol yaitu 8,00 dengan skor terendah 6 dan skor tertinggi 13. Pada hasil uji statistik di dapatkan perbedaan skor nyeri pada kedua kelompok dengan $p$-value $=0,000$ $(p<0,05)$.

\section{PEMBAHASAN}

Nyeri merupakan pengalaman sensori dan emosional yang tidak menyenangkan sebagai akibat dari kerusakan jaringan yang aktual dan potensial, yang menyakitkan tubuh serta diungkapkan oleh individu yang mengalaminya. Ketika suatu jaringan mengalami cedera, atau 
kerusakan mengakibatkan dilepasnya bahanbahan yang dapat menstimulus reseptor nyeri seperti serotonin, histamin, ion kalium, bradikinin, prostaglandin, dan substansi $\mathrm{P}$ yang akan mengakibatkan respon nyeri (Kozier dkk, 2010).

Nyeri pada anak merupakan pengalaman subjektif yang umum terjadi, baik ada kerusakan jaringan aktual maupun tidak. Salah satu yang menjadi sumber utama nyeri yang sering dilakukan pada anak-anak adalah prosedur medis invasif (El-Gawad \& Elsayed, 2014; Silva, Pinto, Gomes, \& Barbosa, 2011). Pemasangan infus merupakan salah satu tindakan invasif yang sering dilakukan dan menyebabkan nyeri akut dan ketakutan pada anak-anak (Sikorova \& Hrazdilova, 2011).

Pemasangan infus dapat kita temukan di setiap ruangan, termasuk di ruang instalasi gawat darurat. Menurut Hartling, et al (2013), pemasangan infus intravena adalah prosedur yang paling umum dilakukan di ruang instalasi gawat darurat dan menyebabkan nyeri pada anak-anak.

Penanganan nyeri dapat dilakukan dengan metode farmakologis dan nonfarmakologis. Di ruang instalasi gawat darurat, metode nonfarmakologi merupakan bagian vital dari perawatan yang diberikan kepada anak-anak dan sangat membantu. Khan (2007) dan Weismann (1998) menyatakan bahwa metode nonfarmakologi merupakan bagian protokol standar instalasi gawat darurat. Sebab, metode nonfarmakologi sangat efektif meminimalisir nyeri dan ketakutan pada anak di ruang instalasi gawat darurat.

Metode nonfarmakologi adalah intervensi keperawatan yang diberikan tanpa menggunakan obat. Berbagai macam metode nonfarmakologi yang dapat dilakukan yaitu metode distraksi salahsatunya dengan pemberian madu. Aplikasi comfort theory dalam penanganan nyeri pada anak dapat diuraikan bahwa aspek health care need yaitu anak memiliki kebutuhan rasa nyaman selama prosedur invasif dilakukan. Aspek nursing intervention yaitu pemberian intervensi nonfarmakologis berupa pemberian madu yang merupakan bagian intervensi keperawatan untuk memenuhi kebutuhan rasa nyaman (Czarnecki, et al, 2011, Skeriptini, 2013).

Dari hasil penelitian di dapatkan bahwa skor nyeri pada kelompok kontrol 8,00 (6-13) lebih besar di bandingkan dengan kelompok intervensi yang diberikan madu dengan skor 5,00 (4-13) dan hasil uji statistik juga di dapatkan perbedaan skor nyeri antara kedua kelompok dengan $p 0,000$.
Perbedaan ini di sebabkan karena madu dapat menurunkan respon nyeri pada anak, hal ini disebabkan komposisi kimia madu mengandung glukosa $(31 \%)$ dan sukrosa $(1,31 \%)$ dan flavonoid. Menurut Kracke et al (2005) glukosa memiliki beberapa mekanisme potensial aksi untuk efek penghilang rasa sakit. Efek analgesik glukosa atau sukrosa ini diduga akibat pelepasan beta endorphin yang merupakan hormon opiat endogen yang diproduksi sendiri oleh tubuh yang bersifat seperti morfin. Selain mekanisme dari preabsorpsi dari rasa manis tersebut juga memberikan efek analgesik karena rasa manis yang dapat merangsang neurotransmiter yang berperan dalam supresi nyeri dan mengeluarkan opiat endogen di kelenjar hipopyse seperti $\beta$ endorpin, begitu juga dengan serotonin dan GABA (gama amino butiryc acid) yang berfungsi menurunkan sensasi nyeri, sedangkan kandungan flavonoid pada madu memblok aksi dari enzim cyklooxygenase yang menghambat pelepasan subtansi prostaglandin, dimana prostaglandin inilah yang akan menyebabkan dikeluarkannya zat-zat mediator nyeri seperti histamin, serotonin yang akan menimbulkan sensasi nyeri (Puspitasari, 2007; Sekriptini, 2013)

Penanganan nyeri dengan pemberian madu memberikan efek menyenangkan yang dapat menurunkan nyeri. Hal ini kemungkinan disebabkan oleh kandungan madu yaitu salah satunya sukrosa yang memberikan rasa manis dan memberikan efek analgesia (Sekriptini, 2013). Hal ini didukung oleh Taddio, Shah dan Katz (2009) yang menyatakan bahwa sukrosa adalah gula alami dengan analgesik dan efeknya menenangkan pada bayi muda. Hal ini dibuktikan oleh penelitian yang dilakukan oleh Kristiawati dkk (2010) di dapatkan bahwa sukrosa efektif dan dapat digunakan sebagai intervensi untuk mengatasi respon nyeri neonatus yang dilakukan tindakan invasif yang menimbulkan nyeri. Hasil penelitian yang dilakukan oleh Harrison et al (2014) menyebutkan pemberian rasa manis (sukrosa, glukosa dan permen karet manis) dapat mengurangi nyeri pada anak usia 1-16 tahun.

Penelitian lain yang serupa dilakukan oleh Susilaningsih dkk (2016) yang membuktikan bahwa pemberian glukosa oral $30 \%$ memberikan pengaruh terhadap respon nyeri pada bayi saat injeksi sampai lima menit setelah injeksi.

Menurut islam madu adalah salah satu minuman yang dimuliakan, melalui Al Qur'an surat An Nahl 68-69 dan hadis.

Rasulullah SAW bersabda,"Hendaklah kalian menggunakan dua obat yaitu madu dan Al Qur'an". (lihat Sunan Ibnu Majah, j.II, h.1142, hadist no. 3452, bab Madu). 
Dan Rabbmu mewahyukan kepada lebah, 'Buatlah sarang-sarang di bukit-bukit, di pohonpohon kayu, dan di tempat-tempat yang dibikin manusia. Kemudian makanlah dari tiap-tiap (macam) buah-buahan dan tempuhlah jalan Rabbmu yang telah dimudahkan (bagimu). 'Dari perut lebah itu keluar minuman (madu) yang bermacam-macam warnanya, didalamnya terdapat obat yang menyembuhkan bagi manusia. Sesungguhnya pada yang demikian itu benar-benar terdapat tanda (kebesaran Rabb) bagi orang-orang yang berfikir.(QS Al-Nahl ayat 68-69)

Oleh karenanya, dalam (Al-Qur'an [16]:68-69) tersebut di atas, Allah SWT secara khusus memperkenalkan manfaat lebah dan produknya kepada umat manusia untuk digunakan sebagai penyembuh berbagai macam penyakit (Suranto, 2004).

\section{DAFTAR PUSTAKA}

Czarnecki, M.L., Turner, H.N., Collins, P.M., Doellman, D., Darcy., Wrona, S., \& Reynolds, J. 2011. Procedural pain management: A position statement with clinical practice recommendations. Pain Management Nursing, 21(11), 1-17.

Dharma, K. 2011. Metodologi Penelitian Keperawatan: Pedoman Melaksanakan dan Menerapkan Hasil Penelitian. Jakarta: Trans Info Media.

El-Gawad, S. M. E \& Elsayed, L. A. 2015. Effect of Interactive Distraction Versus Cutaneous Stimulation for Venipuncture Pain Relief in School Age Children. Journal of Nursing education and Practice, 5(4), 32-40.

Goenarwo, E., \& Susanto, H. 2011. Uji Efektifitas Analgetik Madu pada Tikus dengan Metoda Geliat Asetat Studi Eksperimental pada Tikus Putih Jantan Galur Wistar. Sains Medika, 3(1), 48-53.

Harrison, D., Joly, C., Chretien, C., Cochrane, S., Ellis, J., Lamontagne, C., Vaillancourt, R. 2014. Pain Prevalence in a Pediatric Hospital: Raising Awareness During Pain Awareness Week. Pain Research and Management, 19(1), e24e30.

Hartling, L., Newton, A.S., Liang, Y., Jou, H., Hewson, K., Klassen, T., Curtis, S. 2013. Music to Reduce Rain and Ristress in the Pediatric Emergency Department: a

\section{SIMPULAN}

Ada perbedaan skor nyeri pada kelompok anak yang diberi madu dan tidak diberi madu setelah dilakukan pemasangan infus.

\section{SARAN}

Penelitian ini di harapkan memberikan informasi bagi tenaga kesehatan maupun masyarakat tentang kepada tenaga kesehatan terutama perawat tentang manfaat mengkonsumsi madu untuk mengurangi nyeri dan dapat diaplikasikan sebagai teknik penatalaksanaan nyeri nonfarmakologi pada anak yang dilakukan tindakan invasif seperti pemasangan infus.

Bagi peneliti selanjutnya diharapkan mengembangkan penelitian ini dengan mebandingkan metode penanganan nyeri nonfarmakologi lainya.

Randomized Clinical Trial. JAMA Pediatric, 167(9):826-835.

Kracke, R., Uthoff, A., \& Tobias, D. 2005. Sugar Solution Analgesia: The Effects of Glucose on Expressed mu Opioid Receptors. Anasthesia and analgesia Vol 101, 64-68.

Khan, K.A., \& Weissman, S. J. 2007. Nonpharmocologic Pain Management Strategies in the Pediatric Emergency Department. Clinical Pediatric Emergency Medicine, 8, 240-247.

Kozier. Erb, Berman. Snyder. 2010. Buku Ajar Fondamental Keperawatan: Konsep, Proses \& Praktik, Volume: 1, Edisi: 7, EGC: Jakarta.

Kristiawati, Krisna Yetti, Hening Pujasari. 2010. Pemberian Sukrosa dan NonNutritive Sucking Terhadap Respons Nyeri dan Lama Tangisan Neonatus Pada Prosedur Invasif. Jurnal Ners, Vol. 5, No. 2 Oktober 2010: 127-132.

Mediani, H, S., Mardiyah, A., Rakhmawati, W. 2005. Respon Nyeri Infant dan Anak yang Mengalami Hospitalisasi Saat Pemasangan Infus. http://repository.unpad.ac.id/4031/1/respo n_nyeri_infant.pdf (Diakses pada 5 Juli 2017).

Puspitasari, I. 2007. Rahasia Sehat Madu. Yogyakarta: PT. Bentang Pustaka.

Polit, D.F., \& Beck, C.T. 2012. Nursing 
Research: Generating and Assessing Evidence for Nursing Practice, 9th ed. Philadelpia: Lippincott.

Renolvadi, D., \& Novayelinda, R. Perbandingan Validitas Alat Ukur Nyeri antara Selfreport Pain Scale dan Observational Pain Scale pada Nyeri Akut Anak Usia 3-7 Tahun. Jurnal Online Mahasiswa Program Studi Ilmu Keperawatan Universitas Riau, 1(2), 1-10.

Sekriptini, Yuliani, Ayu. 2013. Pengaruh Pemberian Madu Terhadap Skor Nyeri Akibat Tindakan Invasif Pengambilan Darah Intravena Pada Anak di Ruang UGD RSUD Kota Cirebon. [Skripsi]. Jakarta: Fakultas Ilmu Keperawatan, Universitas Indonesia.

Sikorova, L., \& Hrazdilova, P. 2011. The effect Psychological Intervention on Perceived Pain in Children Undergoing Venipuncture. Biomedical Papers, 155(2), 149-154.

Silva, M. S., Pinto, M. A., Gomes, L. M. X, dan Barbosa, A et al. 2011. Pain in Hospitalized Children: Nursing Team
Perception. Journal of The Sao Paulo, 13(4), 314-320.

Sastroasmoro, S., \& Ismael, S. 2011. Dasardasar Metodelogi Penelitian Klinis, Edisi 4. Jakarta: Sagung Seto.

Suranto, Adji, 2004. Khasiat dan Manfaat madu Herbal. Jakarta: Agromedia Pustaka.

Susilaningsih, E, Zulaica dkk. 2016. Pengaruh Intervensi Glukosa Oral 30\% terhadap Reson Nyeri Bayi dengan Imunisasi di Puskesmas BAKI Sukoharjo. Jurnal Komunikasi Kesehatan, P3M AKBID Purworejo, Edisi 13, Vol 7, No.2.

Taddio, A., Appleton, M., Bortolussi, R., Chambers, C., Dubey, V., Halperin, S., et al. 2010. Reducing The Pain of Childhood Vaccination: an EvidenceBased Clinical Practice Guideline. Canadian Medical Association Journal, 182(18), E843-E855.

Weismann, S.J., Bernstein, B., \& Schechter, N.L. 1998. Consequences of Inadequate Analgesia During Painful Procedures in Children. Arch Pediatr Adolesc Med, 9, 147-152. Agustus 28, 2012. 